\title{
CrimRxiv
}

\section{The Pleasure of Punishment}

\section{Magnus Hörnqvist}

Published on: Mar 19, 2021

License: Creative Commons Attribution 4.0 International License (CC-BY 4.0). 
